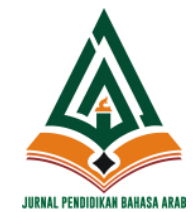

\author{
Alibbaa': Jurnal Pendidikan Bahasa Arab \\ Vol. 2 No. 2, Juli 2021 \\ P-ISSN: 2721-1606 | E-ISSN: 2716-4985 \\ doi: https://doi.org/10.19105/alb.v2i2.4582
}

\title{
Google Meeting Sebagai Media Alternatif di Masa Pandemi Dalam Pembelajaran Maharah Kitabah
}

\author{
Afiffah Vinda Prananingrum \\ State Islamic University of Surakarta \\ E-mail:vindavinda13@gmail.com
}

\begin{abstract}
During online learning, many applications have been launched to support the learning process in the world of education. Starting from the existence of the Learning Management System (LMS), the use of various kinds of Video Conferencing, even to the use of social media which is not a medium for learning but still used for the expected learning to take place. The research objective was to find out how to process and student's responses related to the use of Video conferencing (Google Meet) in learning Khat Imla' in the Arabic Language Education Departement (PBA) in Semester II and IV of IAIN Surakarta. This type of research is qualitative with descriptive methods. The data collection techniques are interviews and questionnaires. The result of this this study is the learning process using Google Meet vide conferencing has been going quite well, seen from the level of student participation in attending lectures is very satisfying. In terms of understanding the material, it is quite understandable by students. However, from the point of view of using google meet to practice writing khat imla', it is still less effective, due to signal problems which cause the video stucked when the lecture is practicing writing khat imla', so that in the training and evaluation process there are still many students who complain of difficulties.
\end{abstract}

Keywords: Google Meeting, Writting Skill. 


\section{Pendahuluan}

Anim dan Nisa dalam Anim dan Mapilindo menjelaskan bahwa di era pandemi seperti sekarang ini, banyak sekali upaya yang dapat diaplikasikan oleh para guru maupun dosen untuk pengembangan kreatifitas skill guna menghasilkan proses pembelajaran yang efektif dan menarik. Hal ini tidak lepas dari fenomena teknologi yang berkembang pesat daripada sebelum adanya pandemi ${ }^{1}$.

Perkembangan teknologi informasi yang sangat pesat di era globalisasi sekarang ini, telah banyak sekali memberikan manfaat pada kehidupan manusia. Banyak hal yang dapat dilakukan dengan mudah dan instan. Tidak dapat dipungkiri jika peran teknologi telah menggantikan peran manusia dalam berbagai bidang sekaligus memperkuatnya. Dalam dunia pendidikan, kecanggihan teknologi memiliki peran yang luar biasa dalam proses pembelajaran. Seperti yang dijelaskan oleh Noor Amalia Audina dan Muassomah bahwa sistem operasi Android IOS dan OS hingga sekarang masih terus diproduksi dengan berbagai macam fitur, sofware, aplikasi dan selalu mengalami perkembangan supaya dapat menunjang kegiatan manusia dari berbagai bidang seperti sosial, ekonomi dan pendidikan ${ }^{2}$.

Video conference menurut Chen merupakan bagian dari synchronous learning yang memiliki arti sebuah kegiatan yang dilaksanakan oleh pendidik dan peserta didik secara berbarengan, dan sifatnya real time. Dengan penggunaan media tersebut dapat memungkinkan peserta didik saling berinteraksi secara bersamaan tanpa harus bertemu dan dalam tempat yang berbeda-beda.

Keterampilan pokok yang wajib dipelajari dalam pembelajaran bahasa arab terdapat empat aspek, seperti maharah al-istima' (keterampilan mendengar), maharah al-kalam (keterampilan berbicara), maharah al-qira'ah (keterampilan membaca), dan maharah al-kitabah (keterampilan menulis). Keempat keterampilan tersebut adalah aspek penting yang tidak dapat dipisahkan. Maharah al-kitabah adalah keterampilan penting dalam bahasa arab dibidang menulis,

\footnotetext{
${ }^{1}$ Anim, \& Malpindo, "Persepsi Mahasiswa Pendidikan Matematika Tentang Pembelajaran Daring Selama Masa Learn From Home (LFH) Pandemic COVID-19", Jurnal Matematic Pedagogic, Vol. 5 No. 1, 2020: 74.

${ }^{2}$ Noor Amalia Audina, \& Muassomah, "Instagram: Alternatif Media Dalam Pengembangan Maharah Al-Kitabah”, Al-Ta'rib: Jurnal Ilmiah Program Studi Pendidikan Bahasa Arab IAIN Palangkaraya, Vol. 8 No. 1, 2020: 78.
} 


\section{ALIBBAA' : Jurnal Pendidikan Bahasa Arab, 2 (1), 2021}

karena dengan menulis dapat mengaktualisasikan kemampuan dan ilmu pada publik ${ }^{3}$.

Pembelajaran khat imla' adalah pembelajaran yang mempelajari tentang menulis bahasa arab. Menurut Lalu Akmal Hijrat menyatakan bahwa khat/kaligrafi merupakan ilmu yang membahas tentang bentukbentuk huruf hijaiyah secara tunggal, seperti cara merangkainya, menempatkannya menjadi sebuah tulisan, menentukan mana yang perlu ditulis dan tidak perlu ditulis, serta mengubah huruf yang perlu dirubah. Adapun pengertian Qowa'idul Imla' yaitu materi khusus keahlian yang dibekalkan kepada mahasiswa ataupun siswa supaya dapat menulis arab dengan baik dan benar. Materi ini disampaikan setelah pemberian materi khat 'araby sebaiknya, supaya tidak hanya mampu menulis dengan benar dan baik, namun juga bagus dan memiliki keindahan ${ }^{4}$.

Dasar penelitian ini yaitu, penelitian yang dilakukan oleh Nalurita dengan judul "Pemanfaatan Aplikasi Google Meet pada Mata Kuliah Teknik Proyeksi Bisnis Semester Gasal Tahun Pelajaran 2020/2021 Diversitas Dirgantara Marsekal Suryadarma (UNSURYA) (Studi Pada Mahasiswa Prodi Manajemen Kelas G”. meneliti tentang analisis respon mahasiswa prodi manajemen setelah pembelajaran menggunakan aplikasi Google Meet. Memperoleh hasil bahwa terdapat 92\% mahasiswa menyatakan mudah dalam penggunaan Google Meet, 79\% mampu memahami materi melalui Google meet, 95, 83\% menyatakan efektif penggunaan Google Meet dalam pembelajaran daring 5 .

Selain itu, dalam penelitian Abdul Haris Rustaman terkait dengan efektivitas penggunaan video conference google meet, Edmodo, dan Instagram pada mata kuliah computer grafis 1 di masa pandemic memperoleh hasil bahwa penggunaan ketiga aplikasi tersebut sangat membantu mahasiswa dalam menjalankan kuliah praktikum pada mata kuliah desain grafis 1. Sedangkan penggunaan Google Meet dapat

\footnotetext{
${ }^{3}$ Miftachul Taubah, "Maharah dan Kafa'ah Dalam Pembelajaran Bahasa Arab." STUDI ARAB: Jurnal Pendidikan Bahasa Arab, Vol. 10 No. 1, 2019: 32-33

${ }^{4}$ Lalu Akmal Hijrat, "Pembelajaran Khat Wa Qowa'idul Imla' Mahasiswa UIN Mataram Dan Problematikanya." Al-Islamiya: Jurnal Pendidikan dan Wawasan Studi Islam, Vol. 2 No. 1, 2020: 5 .

${ }^{5}$ Sari Nalurita, "Pemanfaatan Aplikasi Google Meet Pada Mata Kuliah Teknik Proyeksi Bisnis Semester Gasal Tahun Pelajaran 2020/2021 Di Universitas Dirgantara Marsekal Suryadarma (UNSURYA) (Studi pada Mahasiswa Prodi Manajemen Kelas G)." Jurnal Ilmiah Manajemen Surya Pasca Scientia, Vol. 10 No. 1, 2021: 22.
} 
mengatasi proses asistensi praktikum secara langsung, dapat memahami secara baik cara menggunakannya, serta kegiatan presentasi dan diskusi dapat terlaksana secara langsung ${ }^{6}$.

Ketiga adalah hasil penelitian yang dijabarkan oleh Afief Fakhruddin dengan judul "Using Google Meet In Teaching Speaking" Menjelaskan bahwa pembelajaran dengan memanfaatkan video conference berupa Google Meet mampu meningkatkan speaking skill (ketrampilan berbicara). Jenis penelitian ini adalah tindakan kelas dengan dua cycle. Obyek pada penelitian ini adalah 24 mahasiswa jurusan Pendidikan Bahasa Inggris Universitas Majalengka. Adapun dasar dilakukan penelitian ini yaitu, peneliti menggunakan Google Meet pada pembelajaran speaking (speaking for daily context) pada mahasiswa semester satu jurusan Pendidikan Bahasa Inggris IKIP PGRI Bojonegoro. Peneliti menganalisis tanggapan mahasiswa seusai pembelajaran terkait dengan pembelajaran daring selama pandemic COVID-197.

Dari beberapa dasar penelitian di atas, peneliti ingin membandingkan tentang bagaimana penggunaan Google Meet jika diterapkan pada pembelajaran khat imla', yang lebih dominan pada praktek menulisnya daripada penyampaian materi. Apakah memperoleh hasil penelitian yang sama. Melihat berbagai referensi diatas juga, belum ada penelitian yang menganalisis tentang bagaimana penggunaan Google Meet yang dijadikan sebagai media alternatif dalam pembelajaran maharah kitabah, yaitu pembelajaran khat imla'. Oleh karena itu, peneliti mengambil judul berupa "Google Meeting sebagai Media Alternatif Di Masa Pandemi dalam Pembelajaran Maharah Kitabah". Penelitian ini diharapkan dapat memberikan manfaat untuk bahan evaluasi pembelajaran bahasa arab di berbagai lembaga pendidikan.

\footnotetext{
${ }^{6}$ Abdul Haris Rustaman, "Efektivitas Penggunaan Aplikasi Daring Video Conference dan Sosial Media Pada Mata Kuliah Komputer Grafis 1 Di Masa Pandemi Covid-19." Jurnal Ilmiah Sosial dan Pendidikan, Vol. 4 No. 3, 2020: 561

${ }^{7}$ Afief Fakhruddin, "Using Google Meet in Teaching Speaking." Journal of English

Language Learning (JELL), Vol. 2 No. 2, 2019: 45
} 


\section{Metode Penelitian}

Penelitian ini menggunakan jenis penelitian kualitatif dengan metode deskriptif. Menurut Sugiono, penelitian kualitatif adalah sebuah metode yang bersifat naturalistik dikarenakan meneliti kondisi lingkungan secara alamiah (natural setting) ${ }^{8}$. Adapun dengan metode deskriptif karena memiliki tujuan untuk memaparkan serta mendeskripsikan bagaimana proses penggunaan video conference pada pembelajaran khot imla' bagi mahasiswa dan tanggapan mahasiswa terkait proses pembelajarannya. Subyek penelitian ini adalah Mahasiswa Pendidikan Bahasa Arab (PBA) IAIN Surakarta semester II dan IV dengan jumlah responden sebanyak 25 mahasiswa. Tehnik pengumpulan data berupa wawancara dan kuisioner. Wawancara dilakukan dengan memberikan pertanyaan secara langsung terkait proses pembelajarannya dengan 6 pertanyaan (terkait media yang digunakan, materi yang diajarkan, proses pembelajaran, langkah pengajaran, bagaimana pelatihan serta evaluasi pembelajarannya) kepada responden, yaitu salah satu mahasiswa PBA IAIN Surakarta semester 4 pada Sabtu 03 April 2020 pukul 16.53 sampai dengan 18.53 WIB melalui media sosial WhatsApp. Dikarenakan dosen pengampu mata kuliah khot imla' sama dari semester dua dan semester empat, jadi peneliti mengambil 1 responden saja untuk diwawancara. Adapun dengan kuisioner dilakukan pada hari Ahad 04 April 2021 pukul 08.59 sampai dengan 16.32 dengan jumlah responden sebanyak 21 mahasiswa semester dua dan empat melalui Google Formulir, dengan 17 butir pertanyaan terkait tanggapan mahasiswa terhadap penggunaan Video Conference dalam pembelajaran Khot Imla'. Setelah semua data terkumpul kemudian diolah dengan statistik deskriptif, yaitu tanggapan butir soal diubah menjadi persen jumlah respon. Data tanggapan yang sudah berbentuk alasan ditriangulasi dengan hasil analisis data yang kemudian dibahas dengan mengaitkan pada kajian penelitian dan temuan yang lain.

\footnotetext{
${ }^{8}$ Sugiono, Metode Penelitian Pendidikan: Pendekatan Kuantitatif, Kualitatif, dan R\&D, (Bandung: Alfabeta, 2016), 8
} 


\section{Hasil dan Pembahasan}

\section{a. Langkah dan Proses Pembelajaran}

Pelaksanaan pembelajaran khot imla' dengan penggunaan video conference pada mahasiswa PBA Semester II dan IV di IAIN Surakarta, sudah dimulai sejak awal pembelajaran semester baru. Video conference yang digunakan pada pembelajaran ini berupa video conference Google Meet. Namun dalam pembelajaran ini terdapat media tambahan yang digunakan yaitu media sosial berupa WhatssApp Group, yang berfungsi untuk membagikan materi presentasi dari setiap kelompok sebelum pembelajaran dimulai. Pada pembelajaran khot imla' di semester II dan IV, media yang digunakan adalah sama yaitu mengintegrasikan antara video conference Google Meet dengan media sosial WhatssApp Group, namun penggunaan video conference Google Meet lebih dominan disetiap semester. Informasi ini peneliti dapatkan dari hasil wawancara dan dikuatkan lagi dengan hasil jawaban kuisioner melalui Google Formulir yang diberikan kepada mahasiswa semester 2 dan 4 sebagaimana disajikan pada gambar 1

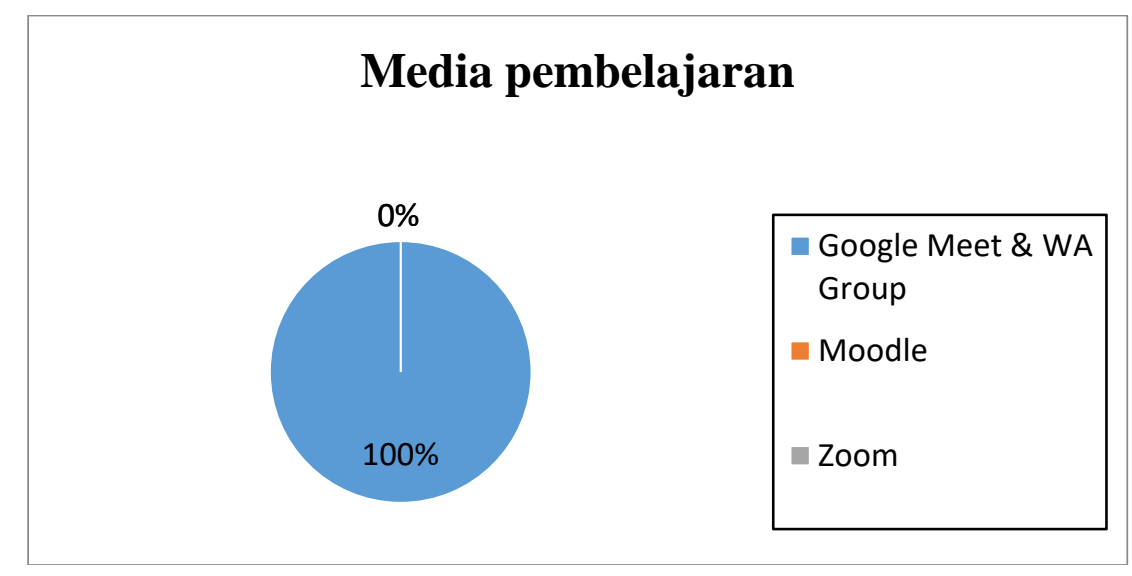

Gambar 1

Media pembelajaran yang digunakan untuk mata kuliah khat imla'

Dapat dilihat pada gambar 1, terdapat 100\% (25) mahasiswa yang memilih media Google Meet dan WA Group, sedangkan 0\% untuk media pembelajaran Moodle dan Zoom. Diambil kesimpulan bahwa pembelajaran khot imla' pada semester II dan IV dengan 
menggunakan pengintegrasian antara video conference Google Meet dan media sosial WA Group.

Materi pembelajaran khot imla' yang telah dipelajari selama kurang lebih setengah semester ini seperti, bagaimana penulisan huruf alif (di awal, tengah, dan akhir), penulisan huruf hamzah (di awal, tengah, dan akhir), penulisan ta taknis. Adapun langkahlangkah dan proses pembelajaran khot imla pada mahasiswa semester II dan IV Jurusan PBA IAIN Surakarta adalah sebagai berikut:

Tabel

Langkah dan Proses Pembelajaran

\begin{tabular}{|l|l|l|}
\hline Kegiatan & \multicolumn{1}{|c|}{ Proses Pembelajaran } & Media \\
\hline Awal & • Dosen membuka kelas & WhatsApp \\
& $\begin{array}{l}\text { Presentator membagikan } \\
\text { PowerPoint materi. }\end{array}$ & Group \\
& $\begin{array}{l}\text { Mahasiswa lain membaca dan } \\
\text { memahami materi }\end{array}$ & \\
& $\begin{array}{l}\text { Dosen mempersilahkan untuk 3 } \\
\text { penanya pada presentator }\end{array}$ & \\
\hline Inti & $\begin{array}{l}\text { Dosen mempersilahkan mahasiswa } \\
\text { bergabung pada Google Meet }\end{array}$ & $\begin{array}{c}\text { Google } \\
\text { Meeting }\end{array}$ \\
& $\begin{array}{l}\text { Dosen menunjuk satu persatu } \\
\text { mahasiswa secara acak untuk } \\
\text { praktek penulisan yang benar. }\end{array}$ & \\
& Penutup dan evaluasi dari dosen & $\begin{array}{c}\text { Google } \\
\text { Meeting }\end{array}$ \\
\hline Akhir & & \\
& & \\
\hline
\end{tabular}

Sumber: Hasil Wawancara, Sabtu 03 April 2020 pukul

Tabel di atas adalah hasil wawancara (Sabtu 03 April 2021) dengan salah satu mahasiswa Semester IV yang menjelaskan bahwa langkah awal pembelajaran khot imla' dimulai dengan dosen membuka kelas, lalu dilanjutkan dengan presentator untuk membagikan materi dalam bentuk PowerPoint. Teruntuk mahasiswa yang tidak bertugas presentasi, dosen memberikan waktu beberapa menit untuk membaca dan memahami materi. Setelah itu, dosen memberikan kesempatan bertanya untuk 3 orang 
mahasiswa saja. Selesai sesi tanya jawab, mahasiswa dipersilahkan bergabung ke Google Meet untuk melakukan praktek menulis khat. Proses pembelajaran ini dilakukan dosen dengan menunjuk satu persatu mahasiswa secara acak untuk mempraktekkan menulis materi yang sudah dibahas atau dipresentasikan, dengan cara menuliskan langsung dengan posisi tangan dihadapkan pada kamera supaya dosen dapat langsung menilai, apakah tulisan yang sudah ditulis dalam bentuk khat sudah benar. Di akhir, dosen menutup pembelajaran dengan mengevaluasi secara bersama terkait pembelajaran yang sudah dilakukan dari awal hingga akhir perkuliahan.

Walaupun dalam keadaan pandemi, sistem pembelajaran yang masih saja dilakukan secara daring, partisipasi dari mahasiswa juga sangat baik. Hal ini dapat dilihat pada gambar 2 yang peneliti paparkan sebagaimana berikut:

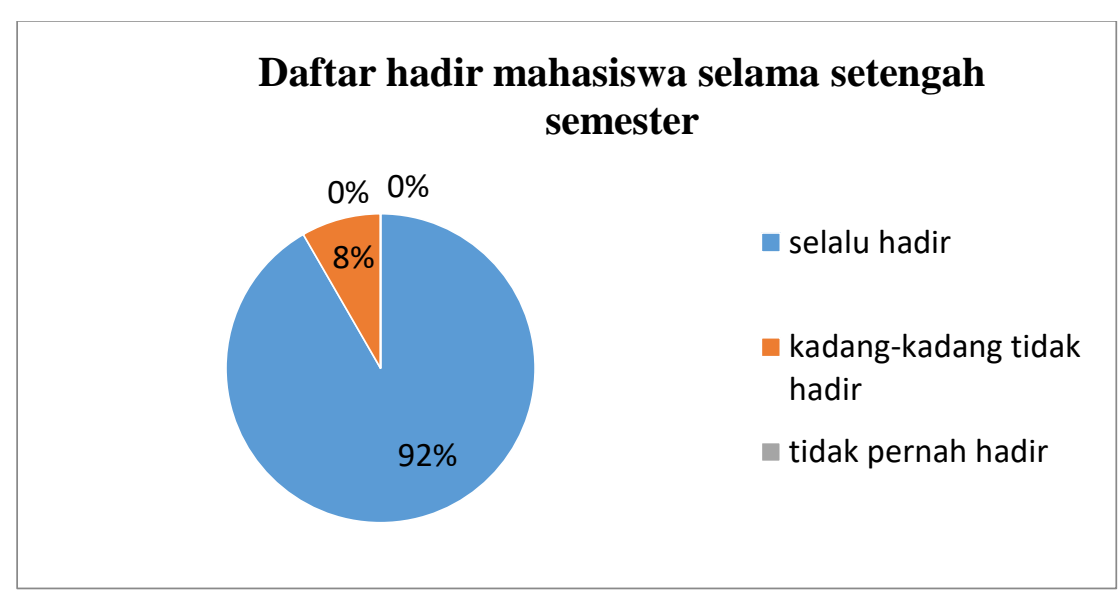

Gambar 2

Daftar hadir mahasiswa selama setengah semester

Dapat dilihat pada gambar 2, daftar hadir mahasiswa selama setengah semester. Terdapat $92 \%$ (23) mahasiswa yang menyatakan selalu hadir dalam pembelajaran khat imla', $8 \%$ (2) mahasiswa yang menyatakan kadang-kadang tidak hadir dan $0 \%$ atau tidak ada yang menyatakan tidak pernah hadir dalam pembelajaran. Hal ini dapat dikatakan bahwa tingkat partisipasi mahasiswa sangatlah bagus. Walaupun terdapat beberapa kendala yang dialami mahasiswa (dituliskan dalam Google Form sebagai 
jawaban atas pertanyaan) dalam mengikuti proses pembelajaran seperti kendala sinyal dan kuota karena menggunakan Google meet membutuhkan cukup kuat sinyal serta kuota, kemudian jam mulai perkuliahan yang terkadang tidak tepat membuat mahasiswa memilih untuk meninggalkan dan melakukan pekerjaan lainnya.

Dalam artikel yang ditulis oleh Al-Maroof, Salloum, Hassanien \& Shaalam menjelaskan pengertian Google Meet adalahaplikasi yang aman digunakan dan sangat direkomendasikan disaat pandemic covid-19. Dianggap sebagai solusi potensial dalam kegiatan belajar mengajar. Selain itu juga disebut sebagai alat komunikasi langsung. Beberapa keunggulan Google Meet dibandingkan sarana komunikasi lainnya seperti, mudahnya pengaksesan di laptop dan smartphone ${ }^{9}$. Teori tersebut dapat dibuktikan dengan adanya hasil penelitian diatas.

\section{b. Pengaruh Penggunaan Video Conference Terhadap Pemahaman Siswa}

Pada sub bab ini, peneliti ingin mendeskripsikan terkait dengan pengaruh penggunaan video conference terkait dengan pemahaman mahasiswa, apakah dengan penggunaan Google Meet dalam pembelajaran khat imla' di masa pandemic ini dapat membantu mahasiswa untuk memahami serta mendapatkan materi secara menyeluruh layaknya pembelajaran ketika didalam ruangan perkuliahan. Sebagaimana dalam gambar 3:

\footnotetext{
${ }^{9}$ Al-Maroof, R. S., Salloum, S. A., Hassanien, A. E., \& Shaalan, K., "Fear From COVID19 and Technology Adoption the Impact of Google Meet During Coronavirus Pandemic", Interactive Learning Environtment, Vol. 0 No. 0, 2020: 1-16
} 


\section{Tingkat pemahaman materi mahasiswa}

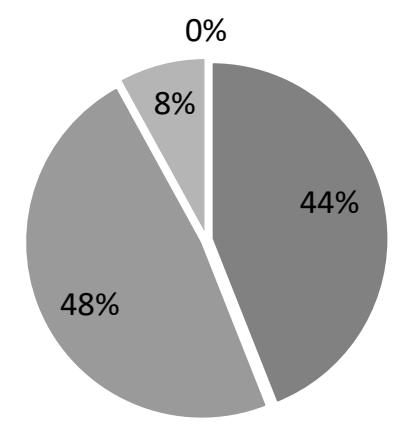

mudah difahami

- kadang-kadang

sulit difahami

\section{Gambar 3}

Pengaruh penggunaan Google Meet pada tingkat pemahaman materi

Dari gambar 3 di atas dapat dijelaskan bahwa hampir keseluruhan materi yang telah disampaikan pada pembelajaran khat imla mampu difahami oleh mahasiswa. Dengan rincian $44 \%$ (11) mahasiswa menyatakan bahwa materi yang disampaikan oleh dosen mudah difahami, 48\% (12) mahasiswa menyatakan kadangkadang materi mudah difahami, namun kadang-kadang sulit difahami, yang terakhir terdapat $8 \%$ (2) mahasiswa menyatakan materi yang disampaikan dosen sulit untuk difahami.

Secara penyampaian materi menurut mahasiswa hampir mudah untuk difahami, namun pada saat ditanya terkait praktek menulis khatnya ketika proses pembelajaran, mahasiswa banyak yang merasa kesulitan. Dari jawaban kuisioner yang disebarkan melalui google formulir dapat disimpulkan seperti: 1) pada saat dosen mempraktekkan menulis khat, terkadang pada saat itu juga sinyal tidak mendukung atau kuota limited, jadi seketika video pada Google Meet terputus-putus bahkan keluar masuk sendiri. 2) karena khat imla' pembelajarannya yang lebih dominan pada praktek, jadi kurang efektif jika menggunakan Google Meet, yang sewaktu-waktu video dan bisa saja terjeda. 3) karena dengan belajar secara daring mahasiswa tidak bisa berinteraksi dengan dosen secara gamblang dan kurang cakap, sedangkan mata kuliah 
imla' lebih mengacu pada latihan penulisan, bagaimana menulis sesuai kaidah khat yang benar, bahkan cara memegang pena pun juga harus benar. Dari alasan tersebut dapat diartikan jika penggunaan video conference Google Meet cocok jika digunakan untuk pembelajaran khat imla' hanya pada penjelasan materi saja, namun untuk praktek menulis khat mahasiswa masih kurang optimal dan maksimal.

Dalam tulisan Sette-de-Souze dengan judul "Motivating Learners in Pandemic Period Through WhatsApp and Google Meet" dijelaskan bahwa penggunaan Google Meet untuk belajar merupakan waktu yang relaksasi, mempermudah belajar dalam keadaan social distancing, untuk akademisi dan para pelajar dapat tetap terhubung untuk terus belajar bersama dalam jarak jauh ${ }^{10}$. Dengan melihat hasil dari tanggapan diatas dengan alasan-alasan yang telah disampaikan oleh mahasiswa PBA semester II dan IV IAIN Surakarta, dapat diartikan bahwa Google Meet tidak selalu dapat mempermudah kegiatan belajar mengajar seperti yang dijelaskan pada teori tersebut. Namun hanya pada mata pelajaran atau mata kuliah tertentu saja. Penggunaan google meet akan sangat mempermudah kegiatan belajar mengajar seperti untuk penyampaian materi dan diskusi, sedangkan untuk pembelajaran yang dominan pada prakteknya (contohnya pada pembelajaran khat imla') masih kurang efektif.

\section{c. Pelatihan dan Evaluasi}

Sistem pelatihan pada pembelajaran khat imla' jurusan PBA di IAIN Surakarta menurut hasil wawancara, dengan melatih dan praktek menulis setiap selesai penjelasan materi pada saat perkuliahan. Untuk menguatkan lagi skill menulis mahasiswa, dosen terkadang memberikan tugas tambahan seperti menuliskan huruf alif menggunakan kaidah khat, menuliskan surah-surah pendek dengan kaidah khat serta menuliskan materi khat dalam kitab rujukan dosen pengampu dengan menggunakan kaidah penulisan khat. Respon siswa terhadap tugas pelatihan yang telah diberikan oleh dosen pengampu ada berbagai macam mulai dari respon positif dan negative seperti pada hasil jawaban kuisioner yang sudah peneliti sebarkan yaitu terdapat $56 \%$ (14) mahasiswa

\footnotetext{
${ }^{10}$ Sette-de-Souze, P. H, "Motivating Learners In Pandemic Period Through WhatsApp and Google Meet." Jurnal Dental Education, 2020: 2-3, https://doi.org/10.1002/jdd.12352
} 
yang merespon bahwa dosen banyak sekali dalam memberikan tugas, tugas satu belum selesai sudah diberikan tugas lagi, terkadang deadline tugas yang diberikan beriringan dengan deadline tugas pada mata kuliah yang lainnya, tugas yang diberikan oleh dosen terkadang suka mendadak, karena terkadang belum memahafi terkait penulisan kaidah khat pada praktek yang disampaikan tapi dosen malah memberikan tugas. Kemudian 32\% (8) mahasiswa menyatakan kadang-kadang penugasan yang diberikan menjadi beban, namun kadang-kadang tidak menjadi beban. Yang terakhir 12\% (3) mahasiswa menyatakan penugasan pada mata kuliah khat imla' tidak menjadi beban, karena merespon bahwa penugasan dibuat enjoy saja, dan berat atau tidaknya tugas ini selama masa pandemi dengan keadaan pembelajaran yang seperti ini memang sudah wajar, tergantung bagaimana kita menyikapinya, jadi kembali lagi pada pribadi masing-masing.

Sedangkan untuk proses evaluasi pada pembelajaran khat imla' di tengah semester ini (UTS) pada masa pandemi seperti, menulis surat Al-Fatihah sesuai kaidah khat, menulis ulang kitab 15 lembar yang berbentuk pdf yang berjudul قواعد فى الاملاء karya Syekh Utsaimin. Semua tugas UTS ditulis menggunakan pena khat kaligrafi. Dalam penugasan UTS untuk evaluasi pembelajaran khat imla' ini, pada semester II dan IV sama, penjelasan dari hasil jawaban kuisioner yang telah disebarkan kepada responden. Tanggapan mahasiswa terkait tugas UTS tersebut sebagaimana pada gambar 4 di bawah: 
ALIBBAA': Jurnal Pendidikan Bahasa Arab, 2 (1), 2021

\section{Respon mahasiswa tentang tugas UTS}

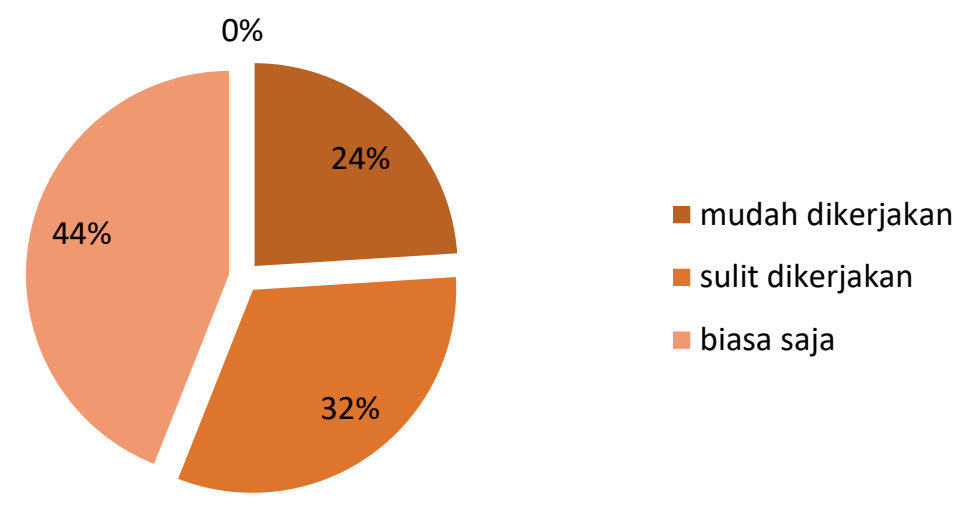

Gambar 4

Respon mahasiswa terkait penugasan UTS

Dari gambar 4 di atas dapat disimpulkan bahwa terdapat $32 \%$ (8) mahasiswa yang menanggapi bahwa tugas untuk UTS tersebut sulit dengan alasan deadline yang terlalu cepat, kurangnya dalam memahami praktek penulisan khat, waktu dalam pengerjaan terhimpit dengan deadline tugas mata kuliah lainnya. Namun ada $24 \%$ (6) mahasiswa yang menanggapi bahwa tugas UTS itu mudah saja karena diri sendiri lah yang terkadang malah mempersulit seperti malas mengerjakan, sering menunda-nunda, tidak adanya niat mengerjakan, kurangnya cekatan dalam mengatur waktu dan membaginya. Dan terdapat 44\% (11) mahasiswa yang memiliki anggapan bahwa tugas UTS ini biasa saja, tidak memberatkan dan juga tidak mudah.

Jika dilihat dari hasil deskripsi analisis data diatas, bahwa langkah-langkah serta proses pembelajaran yang telah diterapkan oleh dosen dengan penggunaan video conference Google Meet sebenarnya sudah baik, hanya saja tidak cocok jika untuk praktek mahasiswa dalam penulisan khat kaligrafi. Namun ditinjau dari segi kognitif, sikap, dan ketrampilan mahasiswa sudah mampu mengikuti pembelajaran khat imla' tanpa ada kendala, hal ini terlihat dari tingkat partisipasi mahasiswa dalam mengikuti perkuliahan. Hanya saja mungkin ada kendala eksternal dari mahasiswa terkait jaringan sinyal yang terkadang kurang 
bersahabat, media pembelajaran yang kurang sesuai dengan praktek kepenulisan.

Adapun dari segi pemahaman dapat dikatakan belum keseluruhan materi dapat difahami oleh mahasiswa, khusunya pada praktek menulis khatnya, banyak mahasiswa juga merespon kesulitan pada materi praktek menulis tersebut. Dari segi pelatihan dan evaluasi dapat dikatakan bahwa sistem penugasan yang diberikan oleh dosen banyak dianggap sulit oleh mahasiswa karena dalam proses pembelajaran yang berkaitan dengan praktek menulis masih kurang maksimal dan mengalami tidak sedikit kendala, sedangkan bentuk penugasan untuk pelatihan dan UTS lebih mengerucut pada praktek menulisnya serta deadline tugas yang rentan waktunya dianggap pendek. Jadi mahasiswa merasa penugasan tersebut sulit dan menjadi beban.

Dapat diartikan bahwa media yang digunakan dalam proses pembelajaran memiliki pengaruh yang besar pada pemahaman mahasiswa serta evaluasinya. Telah dijelaskan oleh Muh. Khobiiru Siroj dalam hasil penelitiannya bahwa media pembelajaran bahasa arab sebagai bagian penting dalam berlangsungnya kegiatan belajar mengajar serta untuk meningkatkan kualitas SDM pengajar supaya professional $^{11}$. Dalam pembelajaran khat imla' ini dengan media google meet masih kurang efektif karena beberapa kendala. Sehingga dalam pelatihan tugas akhir dan evaluasi masih kurang maksimal. Setara dalam tulisan Septaningtyas dalam Yuniarta. I. P menjelaskan bahwa google meet memberikan kemudahan bagi para mahasiswa supaya dapat diakses dimanapun dengan alasan didaerah yang mempunyai sinyal yang bagus dan kuat ${ }^{12}$.

$$
\begin{aligned}
& \text { 11محمّد خبير سراج, "قعالية التعلمية عبر الإنترنت باستعمال تطبيق الواتساب واليتيوب على تعليم قواعد اللغة العربية لدى العي } \\
& \text { الطلاب كليات الاقتصاد والأعمال الإسلامية جامعة "تولونج أكونج" الإسلامية الحكومية تولونج أكونج جاوا الشرقيّة, } \\
& \text { (التدريس: المجلد السامن- العدد الثان, 2020), ص. } 203
\end{aligned}
$$

12 Yuniarti Ita Purnama, “Analisis Respon Mahasiswa Terhadap Pengimplementasian Google Meet pada Mata Kuliah Speaking for Daily Context." PROSIDING SEMINAR NASIONAL PENELITIAN DAN PENGABDLAN, 237-241 


\section{Kesimpulan}

Dapat diambil kesimpulan bahwa langkah-langkah dan proses dalam pembelajaran khat imla' dengan menggunakan video conference google meet sudah berjalan cukup baik, dilihat dari tingkat partisipasi mahasiswa dalam mengikuti perkuliahan sangat memuaskan. Dari segi pemahaman materi, cukup dapat difahami dan dimengerti oleh mahasiswa. Akan tetapi dilihat dari sisi penggunaan google meet untuk praktek menulis khat imla' masih kurang efektif, karena kendala sinyal yang mengakibatkan video terputus-putus ketika dosen pengajar sedang mempraktekkan menulis khat imla', sehingga dalam proses pelatihan dan evaluasi masih banyak mahasiswa yang mengeluh kesulitan.

Saran untuk para pengajar, sebaiknya tidak memilih dan menggunakan video conference Google Meet untuk pembelajaran maharah kitabah yaitu khat imla', karena pembelajaran lebih dominan pada prakteknya bukan pada penyampaian materi dan diskusi. Dilihat dari hasil penelitian diatas dan respon dari para mahasiswa, bahwa penggunaan google meet untuk pembelajaran kitabah masih kurang efektif.

\section{Daftar Pustaka}

$$
\begin{aligned}
& \text { سراج, محمّد خبير. (2020) "فعالية التعلمية عبر الإنترنت باستعمال تطبيق الواتساب } \\
& \text { واليتيوب على تعليم قواعد اللغة العببية للدى الطلاب كليات الاقتصاد والأعمال } \\
& \text { الإسلامية جامعة "تولونج أكونج" الإسلامية الحكومية تولونج أكونج جاوا } \\
& \text { الشرقيّة" ـ التدريس: المجلد الثامن - العدد الثاني، } 2020 .
\end{aligned}
$$

Al-Maroof, R. S., Salloum, S. A., Hassanien, A. E., \& Shaalan, K. "Fear From COVID-19 and Technology Adoption: The Impact of Google Meet During Coronavirus Pandemic.", Interactive Learning Environtments, 2020.

Anim dan Mapilindo. "Persepsi Mahasiswa Pendidikan Matematika Tentang Pembelajaran Daring Selama Masa Learn from Home 
(LFH) Pandemic COVID-19", Jurnal: Matematics Pedagogic, Vol. 5 No. 1, 2020.

Audina, Noor Amalia dan Muassomah. "Instagram: Alternatif Media Dalam Pengembangan Maharah Al-Kitabah", Al-Ta'rib: Jurnal Ilmiah Program Studi Pendidikan Bahasa Arab IAIN Palangkaraya, Vol. 8, No. 1, 2020.

Chen, N. S., Ko, H. C., Kinshuk, \& Lin, T. "A Model for Synchronous Learning using The Internet", Innovations in Education and Teaching International, 2005.

Ekawardhana, Nattaya Emeralda. "Efektivitas Pembelajaran Dengan Menggunakan Media Video Conference", Seminar Nasional Ilmu Terapan IV, A 9-5, 2020.

Fakhruddin, Afief. "Using Google Meet In Teaching Speaking", Journal of English Language Learning (JELL), Vol. 2, No. 2, 2019.

Hijrat, Lalu Akmal. "Pembelajaran Khat Wa Qowa'idul Imla' Mahasiswa UIN Mataram Dan Problematikanya", Al-Islamiyah: Jurnal Pendidikan dan Wawasan Studi Islam. Vol. 2, No. 1, 2020.

Ita Purnama, Yuniarta. “Analisis Respon Mahasiswa Terhadap Pengimplementasian Google Meet Pada Mata Kuliah Speaking for Daily Context", PROSIDING SEMINAR NASIONAL PENELITIAN DAN PENGABDIAN, 2021.

Nalurita, Sari. (2021) "Pemanfaatan Aplikasi Google Meet Pada Mata Kuliah Teknik Proyeksi Bisnis Semester Gasal Tahun Pelajaran 2020/2021 Di Universitas Dirgantara Marsekal Suryadarma (UNSURYA) (Studi pada Mahasiswa Prodi Manajemen Kelas G)”, Jurnal Ilmiah Manajemen Surya Pasca Scientia, Vol. 10, No. 1, 2021.

Rustaman, Abdul Haris. (2020) "Efektivitas Penggunaan Aplikasi Daring, Video Conference Dan Sosial Media Pada Mata Kuliah Komputer Grafis 1 Di Masa Pandemi Covid-19", Jurnal Ilmu Sosial dan Pendidikan, Vol. 4 No. 3, 2020.

Sette-de-Souze, P. H. (2020) "Motivating Learners in Pandemic Period Throug WhatsApp and Google Meet", J Dent Educ. 2021; 85 (Suppl. 1). 
ALIBBAA': Jurnal Pendidikan Bahasa Arab, 2 (1), 2021

Sugiyono. Metode Penelitian Pendidikan: pendekatan Kuantitatif, Kualitatif, dan R\&D. Bandung: Alfabeta, 2016.

Taubah, Miftachul. "Maharah dan Kafa'ah Dalam Pembelajaran Bahasa Arab", STUDI ARAB: Jurnal Pendidikan Bahasa Arab, Vol. 10, No. 1, 2019. 